\title{
Demonstration of Decolorization of Various Dyes by Some Bacterial Isolates Recovered from Textile Effluents
}

\author{
K. R. Mahbub, J. Ferdouse and M. N. Anwar* \\ Department of Microbiology, University of Chittagong, Chittagong -4331, Bangladesh
}

\begin{abstract}
In the present study some predominant bacteria from textile effluent were isolated and their decolorizing activity was evaluated. Heavy load of bacteria $\left(1.3 \times 10^{3}\right.$ to $\left.3.07 \times 10^{7} \mathrm{cfu} / \mathrm{ml}\right)$ were found in eight effluent samples collected from two textile industries. Six dye decolorizing bacteria were isolated and identified as Bacillus fastidiosus, Bacillus polymyxa, Bacillus licheniformis, Bacillus megaterium, Staphylococcus aureus and Micrococcus luteus. The isolates were tested for their ability to decolorize different concentrations $(0.01,0.05$ and $0.1 \%)$ of six different textile dyes. Among the dyes Terasil red W-FS and Terasil black W-NS were found to be completely decolorized by the all isolates at different concentrations. Cibacron yellow F-4G was decolorized very easily by B. fastidiosus while the other dyes were only partially decolorized by the test organisms. Cibacron blue FN-R, Cibacron navy FN-B and Cibacron orange FN-R were only weakly decolorized by the most of the isolates. The results of the present study show that B. fastidiosus, B. polymyxa, M. luteus and $S$. aureus were the potential isolates in the treatment of dyeing industry effluents and their potentiality can be exploited to clean up the environment.
\end{abstract}

Key words: Bacteria, Effluent, Dye, Decolonization.

\section{Introduction}

In general, the wastewater from a textile industry is characterized by high values of BOD, COD, color and $\mathrm{pH}$ (ISPCH, 1995). Because of the high BOD, the untreated textile wastewater can cause rapid depletion of dissolved oxygen. The effluents with high levels of COD are toxic to biological life (Metcalf and Eddy, 1991). Color is one of the most obvious indicators of water pollution and discharge of highly colored synthetic dye effluents can be damaging to the receiving water bodies (Nigam et al. 1996, Rao and Datta, 1987). Over $7.0 \times 10^{5}$ metric tonnes of synthetic dyes are commercially produced worldwide every year (McMullan et al.2001). Two percent of these dyes are directly discharged as aqueous effluent and $10 \%$ are subsequently lost during textile coloration processes (Pearce et al. 2003). The release of colored compounds into water bodies is undesirable not only because of their impact on photosynthesis of aquatic plants but also due to the carcinogenic nature of many of these dyes and their breakdown products (Weisburger, 2002). These compounds are characterized by aromatic rings linked by an azo group, $\mathrm{N}=\mathrm{N}$. The azo linkage of azo dyes may undergo metabolic cleavage resulting in free aromatic amines which are

*Corresponding author: E-mail: jissanmicro_cu@yahoo.com recognized as possible human carcinogens (Banat et al., 1996). Some of the dyes or their breakdown products also have a strong toxic and mutagenic influence on the living organisms (Pinheiro et al., 2004).

In recent years, the control of water pollution has become important in all concerned levels. Removal of dyes from effluents is done usually by physicochemical means. Such methods are costly, less efficient and although the dyes are removed, accumulation of concentrated sludge creates a disposal problem. There is a need to find alternative treatments which are effective in removing dye and low in cost, such as biological or combination systems (Robinson et al. 2001, Kabdasli, 2000). Microbial decolorization and degradation is an environment friendly and cost competitive alternative to chemical decomposition processes (Verma and Madamwar, 2003).

As color is the main contaminant of dyeing industry effluent, the present study was therefore aimed to isolate bacteria from dyeing industry effluent which have the ability to decolorize higher concentrations of six different textile dyes. 


\section{Materials and Methods}

\section{Collection of samples}

Effluent samples from different sites of two textile mills, viz., K. D. S Textile Mills, Bayezid, Chittagong and Coats Bangladesh Ltd, Shagorica, Chittagong were collected in sterile glass bottles. The location of sampling, color, $\mathrm{pH}$ and temperature of the collected samples were recorded carefully at the time of sample collection. After collection, samples were transported to the laboratory without delay and preserved in the refrigerator at $4^{\circ} \mathrm{C}$ before and after the microbial analysis.

\section{Determination of biological oxygen demand (BOD) and chemical oxygen demand (COD) of the samples}

For the determination of the BOD of collected samples, two bottles were filled with the sample. At first, the dissolved oxygen (D.O.) for one BOD bottle was calculated and the rest was kept in dark condition for five days. After five days, the D.O. for the bottles was calculated. Then the BOD level of the sample was determined from the difference between the initial and final D.O.

BOD $(\mathrm{mg} / \mathrm{l})=$ Initial D.O. - Final D.O.

To determine COD of the effluent sample, $50 \mathrm{ml}$ of waste water was transferred in a $100 \mathrm{ml}$ conical flask. Similarly 50 $\mathrm{ml}$ distilled water was taken in a conical flask as control. To each flask $5 \mathrm{ml} \mathrm{K}{ }_{2} \mathrm{Cr}_{2} \mathrm{O}_{7}$ solution was added and placed in boiling water $\left(100^{\circ} \mathrm{C}\right)$ for 1 hour. Thereafter the flasks were cooled for 10 minutes and $5 \mathrm{ml} \mathrm{KI}$ solution and $10 \mathrm{ml}$ of $\mathrm{H}_{2} \mathrm{SO}_{4}$ solution were added to each flask. The content was titrated against Sodium thiosulphate $(0.1 \mathrm{M})$ till the pale yellow color was disappeared. The amount of sodium thiosulphate consumed was recorded. After titration, $1 \mathrm{ml}$ of starch solution was added to the flasks. The color was turned blue. Again these were titrated with sodium thiosulphate till complete disappearance of blue color. The volume of sodium thiosulphate used was noted for the both samples.

COD was calculated using the following formula

$\mathrm{COD}(\mathrm{mg} / \mathrm{L})=\frac{8 \times \mathrm{C} \times \mathrm{V}_{\mathrm{B}}-\mathrm{V}_{\mathrm{A}}}{\mathrm{V}_{\mathrm{S}}}$

Where, $\mathrm{C}=$ Concentration of titrant

$\mathrm{V}_{\mathrm{B}}=$ Volume of titrant (ml) used for water samples
$\mathrm{V}_{\mathrm{A}}=$ Volume of titrant ( $\mathrm{ml}$ ) used for control

$\mathrm{V}_{\mathrm{s}}=$ Volume of water sample taken.

\section{Bacteriological analysis}

Nutrient agar medium was used for the enumeration and isolation of bacteria from the industrial effluent samples using dilution plate, pour plate and spread plate techniques. Bacterial colonies were isolated on the basis of their colony morphology and they were identified on the basis of their morphological, cultural, physiological and biochemical characteristics etc. All the characteristics were compared with the standard description of Bergey's Mannual of Determinative Bacteriology, 8th edition (Buchanan and Gibbons 1974).

\section{Dye decolorization test by using individual selected iso- lates}

Selected isolates from the effluent sample were tested to determine their capability to decolorize dyes. For this test, six different dyes used in textile industry were used. The dyes were Cibacron orange FN-R, Cibacron yellow F-4G, Cibacron blue FN-R, Cibacron navy FN-B, Terasil black WNS and Terasil red W-FS. The dyes were mixed with nutrient broth to give $0.01,0.05$ and $0.1(\mathrm{w} / \mathrm{v})$ concentration. The dye mixed broths were dispensed into test tubes $(10 \mathrm{ml}$ per test tube) and autoclaved. The broths were then inoculated with the individual test organisms and incubated at $37^{\circ} \mathrm{C}$ for 7 to 10 days. Controls were maintained without inoculation. The decolorization was observed periodically by comparing with control.

\section{Results and Discussion}

Industrial effluents discharged into river or in land without any treatment can cause severe pollution with carcinogenic substances. Microbes have wide spread capacity to remove, transform and precipitate these chemical pollutants from the surroundings (Raghukumar et al. 2006, Kumar et al. 2005, Faisal and Hasnain, 2004). In this study, textile dyeing effluents were analyzed for isolation and enumeration of predominant bacteria as well as to demonstrate the decolorization activity of these bacteria.

Some physicochemical properties and total bacterial count of the samples were analyzed which are shown in Table I. The temperature and $\mathrm{pH}$ of the collected samples were in the range from 29 to $39^{\circ} \mathrm{C}$ and 5.56 to 8.9 respectively. The color 
Table I: The physicochemical characteristics and total bacterial count of the collected samples

\begin{tabular}{l|c|c|c|c|c|c}
\hline $\begin{array}{l}\text { No. of } \\
\text { sample }\end{array}$ & $\begin{array}{c}\text { Color of } \\
\text { sample }\end{array}$ & $\begin{array}{c}\text { Temperature } \\
\left({ }^{\circ} \mathrm{C}\right)\end{array}$ & $\begin{array}{c}\text { BOD } \\
(\mathrm{mg} / \mathrm{L})\end{array}$ & $\begin{array}{c}\mathrm{COD} \\
(\mathrm{mg} / \mathrm{L})\end{array}$ & $\mathrm{pH}$ & $\begin{array}{c}\text { Total bacterial } \\
\text { count }(\mathrm{cfu} / \mathrm{ml})\end{array}$ \\
\hline 1. & Pink & 39 & 120 & 300 & 6.50 & $1.3 \times 10^{3}$ \\
2. & Ash & 35 & 200 & 350 & 7.16 & $9.5 \times 10^{4}$ \\
3. & Ash & 37 & 240 & 380 & 8.00 & $3.07 \times 10^{7}$ \\
4. & Ash & 32 & 230 & 450 & 8.65 & $2.9 \times 10^{7}$ \\
5. & Blackish & 29 & 250 & 445 & 8.50 & $7.5 \times 10^{6}$ \\
6. & Orange & 38 & 250 & 450 & 8.90 & $2.2 \times 10^{4}$ \\
7. & Colorless & 35 & 50 & 200 & 5.56 & $1.8 \times 10^{6}$ \\
8. & Ash & 34 & 150 & 250 & 7.50 & $2.5 \times 10^{7}$ \\
\hline
\end{tabular}

of the samples was recorded at the time of sampling by visual inspection. The physicochemical properties of the effluents indicate that they were highly contaminated by chemical wastes from the textile industries (Mihir et al. 2006, Sangodoyin 1995).

The BOD of the collected samples from different industries was found to range from 50 to $250 \mathrm{mg} / \mathrm{L}$. Similar findings are also observed by Sangodoyin (1995). The COD of the samples was observed to vary from 200 to $450 \mathrm{mg} / \mathrm{L}$. The total bacterial count of the samples ranged from $1.3 \times 10^{3}$ to $3.07 \times 10^{7} \mathrm{cfu} / \mathrm{ml}$. The bacterial counts reflect that the textile dyeing effluent is a good source of nutrients for certain bacteria (Mihir et al. 2006).

Twenty bacterial isolates were primarily selected and among them seven isolates were finally selected for identification. On the basis of their morphological, cultural and biochemical characteristics, five isolates belonged to the genus Bacillus, one Staphylococcus and the other was Micrococcus. They were provisionally identified as Bacillus fastidiosus, B. polymyxa, B. Licheniformis, B. megaterium, Staphylococcus aureus and Micrococcus luteus on the basis of the limited phenotypic characteristic as descripted in the "Bergey's Manual of Determinative Bacteriology" (Buchanon and Gibbons 1974).

The selected isolates were tested for their ability to decolorize different concentrations $(0.01,0.05$ and $0.1 \%)$ of six textile dyes. After 7 to 10 days of incubation period, satisfactory result of dye decolorization by selected bacteria was found.

Bacillus fastidiosus isolate was found to be very potent in decolorizing the test dyes. This bacterium completely decolorized high $(0.1 \%)$ concentrations of Cibacron yellow F-4G, Terasil black W-NS and Terasil red W-FS within 2-7 days. Cibacron blue FN-R, Cibacron navy FN-B and Cibacron orange FN-R were partially decolorized by $B$. fastidiosus (Table II).

Table II: Dye decolorization test by using Bacillus fastidiosus

\begin{tabular}{|c|c|c|c|c|}
\hline \multirow[t]{2}{*}{ Isolate } & \multirow[t]{2}{*}{ Dyes } & \multicolumn{3}{|c|}{$\begin{array}{c}\text { Decolorization activities/Days at different } \\
\text { concentrations }(\%) \text { of dyes }\end{array}$} \\
\hline & & $0.01 \%$ & $0.05 \%$ & $0.1 \%$ \\
\hline \multirow{6}{*}{$\mathrm{RS}_{2} \mathrm{C}$} & Cibacron orange FN-R & $+++(4)$ & $+++(5)$ & $+(5)$ \\
\hline & Cibacron yellow F-4G & $++++(4)$ & $++++(6)$ & $++++(7)$ \\
\hline & Cibacron blue FN-R & $++++(2)$ & $++++(4)$ & - (10) \\
\hline & Cibacron navy FN-B & $++++(3)$ & $++++(4)$ & - (10) \\
\hline & Terasil red W-FS & $++++(2)$ & $+++(4)$ & $++(4)$ \\
\hline & Terasil black W-NS & $++++(2)$ & $++++(2)$ & $++++(3)$ \\
\hline
\end{tabular}

Note: $++++=$ Complete decolorization, $+++=$ Partial decolorization, $++=$ Weak decolorization, $+=$ Very weak decolorization, - = No decolorization. Numbers within parenthesis indicate days. 
Bacillus polymyxa was able to decolorize different concentrations of Terasil black WNS and Terasil red WFS within 23 days (Table III). Cibacron blue FN-R, Cibacron orange FN-R and Cibacron yellow F-4G were weakly decolorized. No decolorization of Cibacron navy FN-B was observed at any concentration. Bacillus licheniformis was able to decolorize completely Terasil black W-NS at all concentrations within 2-3 days and 0.01 and $0.05 \%$ of Cibacron blue FN-R and Cibacron navy FN-B within 2- 4 days. Low concentration $(0.01 \%)$ of Terasil red W-FS was partially decolorized by $B$. licheniformis in 4 days while the organism could not decolorize Cibacron orange FN-R at any concentration (Table IV).
Cibacron navy FN-B was fully unchanged after 10 days of incubation period. Decolorization of Cibacron blue FN-R and Cibacron yellow F-4G was very weak after 4 to 5 days (Table V).

Terasil red W-FS and Terasil black W-NS of all concentrations were completely decolorized by Staphylococcus aureus. However Cibacron orange FN-R, Cibacron yellow F-4G, Cibacron blue FN-R and Cibacron navy FN-B was weakly decolorized (Table VI).

Micrococcus luteus completely decolorized 0.01, 0.05 and $0.1 \%$ Terasil red W-FS and Terasil black W-NS after 2 to 4

Table III: Dye decolorization test by using Bacillus polymyxa

\begin{tabular}{|c|c|c|c|c|}
\hline \multirow[t]{2}{*}{ Isolate } & \multirow[t]{2}{*}{ Dyes } & \multicolumn{3}{|c|}{$\begin{array}{c}\text { Decolorization activities/Days at different } \\
\text { concentrations }(\%) \text { of dyes }\end{array}$} \\
\hline & & $0.01 \%$ & $0.05 \%$ & $0.1 \%$ \\
\hline \multirow{6}{*}{$\mathrm{RS}_{3} \mathrm{E}$} & Cibacron orange FN-R & $++(5)$ & $-(10)$ & - (10) \\
\hline & Cibacron yellow F-4G & $++(4)$ & $+(7)$ & $+(7)$ \\
\hline & Cibacron blue FN-R & $++++(3)$ & - (10) & - (10) \\
\hline & Cibacron navy FN-B & - (10) & - (10) & - (10) \\
\hline & Terasil red W-FS & $+++(3)$ & $+++(3)$ & $++(3)$ \\
\hline & Terasil black W-NS & $++++(2)$ & $+++++(2)$ & $++++(3)$ \\
\hline
\end{tabular}

Note: $++++=$ Complete decolorization, $+++=$ Partial decolorization, $++=$ Weak decolorization, $+=$ Very weak decolorization, - = No decolorization. Numbers within parenthesis indicate days.

Table IV: Dye decolorization test by using Bacillus licheniformis

\begin{tabular}{l|l|c|c|c}
\hline \multirow{2}{*}{ Isolate } & \multicolumn{3}{|c}{$\begin{array}{c}\text { Decolorization Activities/Days at Different } \\
\text { Concentrations (\%) of Dyes }\end{array}$} \\
\cline { 2 - 5 } & & $0.01 \%$ & $0.05 \%$ & $0.1 \%$ \\
\hline \multirow{3}{*}{$\mathrm{RS}_{1} \mathrm{~J}$} & Cibacron orange FN-R & $-(10)$ & $-(10)$ & $-(10)$ \\
& Cibacron yellow F-4G & $++(4)$ & $+(7)$ & $+(7)$ \\
& Cibacron blue FN-R & $++++(2)$ & $++++(4)$ & $+(5)$ \\
& Cibacron navy FN-B & $++++(4)$ & $++++(4)$ & $-(10)$ \\
& Terasil red W-FS & $+++(4)$ & $++(4)$ & $+(10)$ \\
& Terasil black W-NS & $++++(2)$ & $++++(2)$ & $+++(3)$ \\
\hline
\end{tabular}

Note: $++++=$ Complete decolorization, $+++=$ Partial decolorization, $++=$ Weak decolorization, $+=$ Very weak decolorization, - = No decolorization. Numbers within parenthesis indicate days.

Bacillus megaterium was found to decolorize 0.01 and $0.05 \%$ Terasil black W-NS completely in 2 days and $0.1 \%$ Terasil black W-NS weakly in 3 days. B. megaterium partially decolorized Terasil red W-FS. Cibacron orange FN-R and days. Cibacron orange FN-R, Cibacron navy FN-B, Cibacron blue FN-R and Cibacron yellow F-4G were weakly decolorized (Table VII). 
Table V: Dye decolorization test by using Bacillus megaterium

\begin{tabular}{l|l|c|c|c}
\hline \multirow{2}{*}{ Isolate } & \multicolumn{2}{|c}{ Dyes } & \multicolumn{2}{|c}{ Decolorization activities/Days at different concentrations (\%) of dyes } \\
\cline { 2 - 4 } & & $0.01 \%$ & $0.05 \%$ & $0.1 \%$ \\
\hline \multirow{5}{*}{$\mathrm{RS}_{1} \mathrm{~K}$} & Cibacron orange FN-R & $-(10)$ & $-(10)$ & $-(10)$ \\
& Cibacron yellow F-4G & $++(4)$ & $-(10)$ & $-(10)$ \\
& Cibacron blue FN-R & $+++(4)$ & $-(10)$ & $-(10)$ \\
& Cibacron navy FN-B & $-(10)$ & $-(10)$ & $-(10)$ \\
& Terasil red W-FS & $++++(3)$ & $++(4)$ & $+(6)$ \\
& Terasil black W-NS & $++++(2)$ & $+++++(2)$ & $++(4)$ \\
\hline
\end{tabular}

Note: $++++=$ Complete decolorization, $+++=$ Partial decolorization, $++=$ Weak decolorization, $+=$ Very weak decolorization, - = No decolorization. Numbers within parenthesis indicate days

Table VI: Dye decolorization test by using Staphylococcus aureus

\begin{tabular}{l|l|c|r|r}
\hline \multirow{2}{*}{ Isolate } & \multicolumn{1}{|c|}{ Dyes } & \multicolumn{3}{|c}{ Decolorization activities/Days at different concentrations (\%) of dyes } \\
\cline { 2 - 5 } & & $0.01 \%$ & $0.05 \%$ & $0.1 \%$ \\
\hline \multirow{5}{*}{$\mathrm{RS}_{2} \mathrm{~A}$} & Cibacron orange FN-R & $++(3)$ & $+(10)$ & $-(10)$ \\
& Cibacron yellow F-4G & $++(4)$ & $+(7)$ & $+(7)$ \\
& Cibacron blue FN-R & $+++(3)$ & $+(6)$ & $-(10)$ \\
& Cibacron navy FN-B & $++(6)$ & $++(6)$ & $-(10)$ \\
& Terasil red W-FS & $++++(3)$ & $++++(4)$ & $++++(6)$ \\
& Terasil black W-NS & $++++(2)$ & $+++++(2)$ & $++++(4)$ \\
\hline
\end{tabular}

Note: $++++=$ Complete decolorization, $+++=$ Partial decolorization, $++=$ Weak decolorization, $+=$ Very weak decolorization, - = No decolorization. Numbers within parenthesis indicate days

Table VII: Dye decolorization test by using Micrococcus luteus

\begin{tabular}{|c|c|c|c|c|}
\hline \multirow[t]{2}{*}{ Isolate } & \multirow[t]{2}{*}{ Dyes } & \multicolumn{3}{|c|}{ Decolorization activities/Days at different concentrations $(\%)$ of dyes } \\
\hline & & $0.01 \%$ & $0.05 \%$ & $0.1 \%$ \\
\hline \multirow{6}{*}{$\mathrm{RS}_{1} \mathrm{I}$} & Cibacron orange FN-R & $+(10)$ & $+(10)$ & $-(10)$ \\
\hline & Cibacron yellow F-4G & $++(4)$ & $+(7)$ & $+(7)$ \\
\hline & Cibacron blue FN-R & $+++(3)$ & $+(10)$ & $+(10)$ \\
\hline & Cibacron navy FN-B & $++(7)$ & $+(10)$ & - $(10)$ \\
\hline & Terasil red W-FS & $++++(3)$ & $++++(4)$ & $++++(4)$ \\
\hline & Terasil black W-NS & $++++(2)$ & $+++++(2)$ & $+++(3)$ \\
\hline
\end{tabular}

Note: $++++=$ Complete decolorization, $+++=$ Partial decolorization, $++=$ Weak decolorization, $+=$ Very weak decolorization, - = No decolorization. Numbers within parenthesis indicate days.

Sharnaik and Kaneker (1995) reported similar decolorization potential of Pseudomonas isolated from textile dyeing industry. Decolorization of dye compounds by Pseudomonas, Bacillus and Clostridium were reported by Mihir et al. (2006). Sukumar et al. (2007) reported Bacillus sp. as maximum color reductive bacteria. However Leena and Selva Raj (2008) studied that effluent adapted bacteria are better candidates for decolorizing the effluent. Decolorization and degradation of the reactive dye by Citrobacter sp. CK3 was also reported by Hui et al. (2009). Our findings were in accordance with them.

\section{Conclusion}

Microbial activities can be employed in the degradation of xenobiotic compounds within waste streams and in the bioremediation of environment contaminated by these materials. The present study clearly demonstrated that the naturally occurring bacteria can degrade toxic dyes of various types generated from textile industries in Bangladesh. Such bacteria can be used for pretreatment of textile effluents that can be safely discharged into the environment. 


\section{References}

Banat I. M., Nigam P., Singh D. and Marchant R. (1996). Microbial decolorization of textile dye containing effluents: a review. Bioresource Technology 58: 217-227.

Buchanan R. E and Gibbons N. E. (1974). Bergey's Manual of Determinative Bacteriology. 8th ed. The William and Wilkons Co. Baltimore.

Faisal M. and Hasnain S. (2004). Microbial conversion of $\mathrm{Cr}$ (VI) into $\mathrm{Cr}$ (III) in industrial effluent. African $J$. Biotechnol. 3 (11): 610-617.

Hui W., Jian Q. S., Xiao W. Z., Yun T., Xiao J. X. and Tian L. Z. (2009). Bacterial decolorization and degradation of the reactive dye Reactive Red 180 by Citrobacter sp. CK3. Int Bio Bio. 63(4): 395-399.

ISPCH. (1995). Industrial safety and pollution control handbook, a joint publication of National Safety Council and Associate Publishers Pvt. Ltd, Hyderabad, 2nd edition, pp. 451-466.

Kabdasli I., Gurel M. and Tunary O. (2000). Characterization and treatment of textileprintingwastewaters. Environ. Technol. 21(10):1147-1155.

Kumar R., Moharikar A. and Purohit H. J. (2005). Microbial population dynamics at effluent treatment plants. $J$. Environ. Monit. 7: 552-558.

Leena R. and Selva Raj D. (2008). Biodecolorization of textile effluent containing Reactive Black-B by effluent adapted and non adaptedbacteria. African. $J$. Biotechnol. 7(18): 3309-3313.

McMullan G., Meehan C., Conneely A., Kirby N., Robinson T., Nigam P., Banat I. M., Marchant R. and Smyth W. F. (2001). Microbial decolorization and degradation of textile dyes. Appl. Microbiol. Biotechnol. 56: 81-87.

Metcalf and Eddy (1991). Wastewater Engineering: Treatment, Disposal and Reuse., Mc.Graw Hill Publishing Company, Mc.Graw Hill International editions, Civil Engineering series, Singapore, 3rd edition.

Mihir L. S., Mahbubar R. K and Farida I. (2006). Bacteria associated with textile dyeing industrial effluents and their depolarization potentiality. Bangladesh J. Microbiol. 23(1):52-54.

Nigam P., Banat I .M., Singh D and Marchant R. (1996).
Microbial process for the decolonization of textile effluent containing azo, diazo and reactivedyes. Process Biochem. 31: 435-442.

Pearce C. L., Lioyd J. R and Guthrie J. T. (2003). The removal of color from textile wastewater using whole bacterial cells: a review. Dyes Pigments 58:179-196.

Pinheiro H. M., Tourand E. and Thomas O. (2004). Aromatic amines from azo reduction: status review Mal. J. Microbiol. Vol 5(1) 2009, pp. 25-32 with emphasis on direct UV spectrophotometric detection in textile industry wastewater. Dyes and Pigment, 61: 121-139.

Raghukumar C., Desouza D. T., Tiwari R. and Shah A. K. (2006). Enhanced production of laccase by a marine fungus during treatment of colored effluents and synthetic dyes. Enzyme Microb. Technol. 38(3-4): 504-511.

Rao M. N. and Datta A. K. (1987). Wastewater treatmentRational methods of deign and Industrial practices., Oxford \& IBH Publishing Co. Pvt. Ltd., New Delhi, 2nd edition.

Robinson T., McMullan G., Marchant R. and Nigam, P. (2001). Remediation of dyes in textile effluent: A critical review on current treatment technologies with a proposed alternative. Bioresour Technol. 77(3): 247-255.

Sangodoyin A. Y. (1995). Characteristics and control of industrial effluent generated pollution. Environ. Manag. Health. 6(4): 15-18.

Sharnaik S. and Kaneker P. (1995). Bioremediation of color of methyl violet and phenol from a dye industry waste effluent using Pseudomonas spp isolated from factory soil. J. Appl. Bacteriol. 79: 459-469.

Sukumar M., Sivasamy A. and Swaminathan G. (2007). Appl. Biochem. Biotech.136(1): 53-62.

Verma P. and Madamwar D. (2003). Decolorization of synthetic dyes by a newly isolated strain of Serratiamarcescens. WorldJMicrobiol. Biotechnol. 19: 615-618.

Weisburger J. H. (2002). Comments on the history and importance of aromatic and heterocyclic amines in public health. Mutat. Res. 506/507: 9-20.

Received : July 08, 2010;

Accepted : December 19, 2010 